JOWITA JANICKA

ORCID 0000-0001-5532-5935

Uniwersytet Wroctawski

\title{
„LUBIŁY SZCZEGÓLNIEJ MUZYKĘ, KTÓRA CZĘŚĆ ICH WYCHOWANIA STANOWIŁA". DOMOWA EDUKACJA MUZYCZNA POLSKICH SZLACHCIANEK EPOKI OŚWIECENIA
}

\begin{abstract}
AвSTRACT. Janicka Jowita, „Lubity szczególniej muzykę, która część ich wychowania stanowiła”. Domowa edukacja muzyczna polskich szlachcianek epoki oświecenia ["[They] Liked Music in Particular, Which Was A Part of Their Manners." Home Music Education of Polish Aristocrat Women During the Enlightenment]. Studia Edukacyjne nr 60, 2021, Poznań 2021, pp. 263-278. Adam Mickiewicz University Press. ISSN 1233-6688. DOI: 10.14746/se.2021.60.14

The education and upbringing of youth was one of the main issues considered by the aristocracy of Polish-Lithuanian Commonwealth in the age of the Enlightenment. A significant part of this current was music education (learning to play the instruments, singing and dancing) acknowledged as compulsory for women with reading, writing, learning foreign languages and history altogether. Every well-educated woman aristocrat could elegantly play the instrument and sing. They were gaining that knowledge primarily at home from foreign and domestic teachers. Despite the popularity of such education and constant presence of music during many noble balls, ceremonies and social arrangements, it was unfavorable in the eyes of current educational theoreticians and according to them useless. Yet memoirs offer multiple examples of delight about female musical abilities. Furthermore, music as a fundamental part of education was mentioned by women themselves; the shortcomings were punished. It seems that despite educationalists' complaints music education of women helped them entertain noble guests with their musical talents. Woman with such skills, seeking good and affluent husbands, could successfully conquer male hearts.
\end{abstract}

Key words: Enlightenment, Polish-Lithuanian Commonwealth, education of girls, music

W krakowskim czasopiśmie „Zbiór Wiadomości Tygodniowych” z 1784 roku, w artykule poświęconym ćwiczeniu ciała młodzieży pisano:

Muzyka także do ćwiczenia młodzi potrzeba. Bo jako do astronomii oczy służą, tak uszy do muzyki bądź głosowej bądź instrumentalnej. Muzyka jest zabawką i odpoczynkiem uczciwym, odnawia umysły spracowane (...). Do zdrowia i dużości ciała 
muzyka potrzebna (...), a najwięcej cieszy tych, którzy się bawią naukami, bo duchy osłabiałe wznieca, siły pobudza, umysł strapiony pracą ochładza, tęskność uczenia się odejmuje i gładzi ${ }^{1}$.

Tak jak dzisiaj² ${ }^{2}$ również w epoce oświecenia dostrzegano zalety, jakie niosła ze sobą muzyka i edukacja muzyczna ${ }^{3}$. O nauce muzyki pisał najbardziej popularny pedagog swoich czasów Jan Jakub Rousseau (1712-1778). Widział on konieczność rozwijania słuchu i wrażliwości muzycznej już we wczesnym dzieciństwie. Uznawał też potrzebę tworzenia specjalnych pieśni dla dzieci, które najszybciej przybliżą je do muzyki ${ }^{4}$. Wśród polskich autorytetów, gorącym orędownikiem wychowania muzycznego dzieci i młodzieży był ksiądz Grzegorz Piramowicz (1735-1801)5. W swoim dziele pedagogicznym Powinności nauczyciela mianowicie zaś w szkołach parafjalnych i sposoby ich dopetnienia, wydanym po raz pierwszy w 1787 roku, pisał:

Dzieci nie mogą być zdrowe bez wesołości, bez rozrywek. (...) Pomoże do wesołości zwyczaj śpiewania. Niech mają przystojne, a wesołe pieśni, niech czasem pojedynczo, czasem w kupie wyśpiewują. Tym sposobem, to jest przez pieśni, można wpajać w nich pobożność, miłość bliźniego, chęć do pracy, różne cnoty, obrzydzać występki, próżnowanie i tym podobne ${ }^{6}$.

Jednak pod pojęciem wychowania muzycznego kryła się nie tylko nauka śpiewu. Muzykowanie było dla szlachty w tym czasie równoznaczne z grą na instrumentach, często połączone właśnie ze śpiewem, a także tańcem.

Do głównego kręgu zainteresowań epoki oświecenia należało wychowywanie dzieci oraz młodzieży, w tym także edukacja muzyczna. Reformowano programy i metody nauczania, a problem szkolnictwa stanął w centrum uwagi społecznej ${ }^{7}$. Reforma wychowania uwzględniła również problem kształcenia dziewcząt. W zaleceniach dotyczących ich edukacji oraz rozważaniach teoretycznych odnoszono się do tego, jak oraz czego mają się uczyć. Swoje zdanie na ten temat wygłaszali czołowi liderzy edukacji tych czasów, między innymi: Franciszek Bieliński (ok. 1742-1809), starosta czerski,

\footnotetext{
1 "Zbiór Wiadomości Tygodniowych”, 1784, nr 10, kwartał drugi, s. 150-151.

2 Por. E. Wolińska, Rola zajęć umuzykalniających w rozwoju dziecka, Konteksty Pedagogiczne, 2017, 1(8), s. 261-269; M. Przychodzińska, Wychowanie muzyczne - idee, treści, kierunki rozwoju, Warszawa 1989.

${ }^{3}$ K. Mrozowska, Rozwój koncepcji pedagogicznych w XVIII w., [w:] Pisma i projekty pedagogiczne doby Komisji Edukacji Narodowej, Wrocław - Warszawa - Kraków - Gdańsk 1973, s. V-LXX.

4 Por. J.J. Rousseau, Emil czyli o wychowaniu, wstęp i oprac. J. Legowicz, t. I, Wrocław 1955, s. 173-176.

${ }^{5}$ E. Aleksandrowska, Piramowicz Grzegorz Wincenty, [w:] Polski Słownik Biograficzny, t. 26, Wrocław - Warszawa - Kraków - Gdańsk - Łódź 1981, s. 529-536.

${ }^{6}$ G. Piramowicz, Powinności nauczyciela mianowicie zaś w szkołach parafjalnych $i$ sposoby ich dopetnienia, oprac. W. Osterloff, Łódź 1919, s. 66.

7 Z. Libera, Problemy polskiego Oświecenia. Kultura i styl, Warszawa 1969, s. 47.
} 
później pisarz wielki koronny ${ }^{8}$, książę Adam Kazimierz Czartoryski (17341823), generał ziem podolskich ${ }^{9}$, czy pijar Antoni Maksymilian Prokopowicz (1738-1807), kaznodzieja pedagog, historyk oraz tłumacz ${ }^{10}$. Także Komisja Edukacji Narodowej (KEN), powołana 14 października 1773 roku, w swoich Ustawach... choć w niewielkiej ilości, to poruszała kwestie dotyczące wychowania płci pięknej ${ }^{11}$. Przedstawiane przez wyżej wymienionych teoretyków i KEN programy edukacji zwracały uwagę na wychowywanie kobiet $\mathrm{w}$ duchu patriotycznym. Stawiano nacisk na porządną naukę pisania i czytania języka polskiego oraz znajomości historii własnej ojczyzny ${ }^{12}$, „ażeby dobre obyczaje kwitnęły w kraju"13. Chciano kształcić Polki na dobre obywatelki, zorientowane w sprawach publicznych, które będą działać dla dobra kraju, ponieważ dotychczasowe kosmopolityczne ich wychowanie powodowało, że nie interesowały się one losami swojego państwa, zupełnie jakby z niego nie pochodziły. W czasach, które przyniosły zagrożenie i upadek państwowości, wykreowano tak zwaną Matkę-Spartankę - kobietę, która wychowuje dzieci i świadomie poświęca je na ołtarzu ojczyzny ${ }^{14}$. Dziewczynki miały być właśnie wychowywane w domu, najlepiej przez własną matkę lub odpowiednio wykształconą krajankę ${ }^{15}$.

Gdzie ową edukację pobierały ówczesne Polki? W II połowie XVIII wieku w powszechny zwyczaj weszło powierzanie wychowania córek zagranicznym przybyszom ${ }^{16}$. Edukacja przez nich prowadzona odbywała się w domach, bądź też na coraz częściej pojawiających się w miastach pensjach

\footnotetext{
${ }^{8}$ A. Wolff, W. Budka, Bieliński Franciszek, [w:] Polski Stownik Biograficzny, t. 2, Kraków 1936, s. $50-51$.

${ }^{9}$ H. Waniczkówna, Czartoryski Adam Kazimierz, [w:] Polski Stownik Biograficzny, t. 4, Kraków 1938, s. 249-257.

${ }^{10}$ D. Żołądź-Strzelczyk, Antoniego Maksymiliana Prokopowicza "Sposób nowy najłatwiejszy pisania i czytania razem dla panienek z przypisami dla nauczycielek": pierwszy polski podręcznik edukacji elementarnej dla dziewczat, Kwartalnik Historii Kultury Materialnej, 2014, 62, 4, s. 553-565.

${ }^{11}$ Ustawy Komisji Edukacji Narodowej dla stanu akademickiego i na szkoty w krajach Rzeczypospolitej przypisane w Warszawie roku 1783, wstęp J. Lubczyński, Lwów 1930, s. 59-62.

12 Por. W. Stetkiewiczówna, System wychowania kobiet wedtug KEN, Przegląd Pedagogiczny, 1924, IV, s. 228-235; A.M. Prokopowicz, Sposób nowy, najtatwiejszy, pisania i czytania razem dla panienek, z przypisami dla nauczycielek, Kraków 1790, przedmowa.

${ }^{13}$ F. Bieliński, Sposób edukacji w XV listach opisany, które do Komisji Edukacji Narodowej od bezimiennego autora byty przesytane R. P. 1775, [w:] Pisma i projekty pedagogiczne doby Komisji Edukacji Narodowej, Wrocław - Warszawa - Kraków - Gdańsk 1973, s. 118.

${ }^{14}$ M. Bogucka, Białogłowa w dawnej Polsce. Kobieta w społeczeństwie polskim XVI-XVIII wieku na tle porównawczym, Warszawa 1998, s. 162; D. Żołądź-Strzelczyk, "Jako rządzić mają rodzice córki swe". Poglady na wychowanie kobiet w XVI-XVIII w., [w:] Rola i miejsce kobiet w edukacja i kulturze polskiej, t. 1, red. W. Jamrożek, D. Żołądź-Strzelczyk, Poznań 1998, s. 62.

15 A. Czartoryski, Drugi list Imć Pana Doświadczyńskiego do przyjaciela swego względem edukacyi córek, [w:] S. Tync, Komisja Edukacji Narodowej: (pisma Komisji i o Komisji): wybór źródet, Wrocław 1954, s. 298.

${ }^{16}$ Por. M.G. Zieliński, Rola cudzoziemek w procesie edukacji młodzieży w okresie stanistawowskim (1764-1795), [w:] Rola i miejsce kobiet, s. 102-108.
} 
prywatnych, utrzymywanych i zazwyczaj prowadzonych przez Francuzki (kwestię pensji próbowały regulować m.in. wspomniane wcześniej Ustawy $\mathrm{KEN}^{17}$ ). Dziewczęta powszechnie miały nauczycielki obcego pochodzenia. Pomimo nacisku, jaki starano się położyć na dobre opanowanie ojczystego języka, w Rzeczypospolitej Obojga Narodów panowało silne przekonanie, że znajomość cudzoziemskich języków u kobiet stanowiła podstawę dobrego i starannego wychowania. Lotaryńczyk Hubert Vautrin (1742-1822) przebywający w Rzeczypospolitej w latach siedemdziesiątych XVIII wieku pisał:

Za bardzo zaniedbane uważa się wychowanie panny, która nie umie mówić przynajmniej po francusku. Dotyczy to zresztą jedynie zamożnych domów, toteż o pozostałych dziewczętach nie mówi się nigdy, że otrzymały wychowanie ${ }^{18}$.

Jednak zagraniczne guwernantki miały do zaoferowania więcej, niż tylko nauka języka obcego. Ich obecność w Polsce wiązała się z upowszechnieniem gry scenicznej i rozwojem zainteresowania życiem kulturalnym. Uczyły one swoje wychowanice literatury, haftu, a w szczególności na bardzo dobrym poziomie muzyki, śpiewu, czy tańca ${ }^{19}$. Ogłoszenia pojawiające się często w prasie warszawskiej wyraźnie pokazywały ofertę nauczycielek i nauczycieli obcego pochodzenia. W "Gazecie Warszawskiej” anonsował się

pewien jegomość, umiejący doskonale po niemiecku, po łacinie i nieco po polsku, przy tym gra na skrzypcach, fletrowersie i na basetli, życzyłby sobie przystać do dzieci w charakterze guwernera ${ }^{20}$.

Kolejne ogłoszenie donosi:

Pani Joanna Mayern, rodem z Monachium, przybyła przed tygodniem z Królewca do tutejszej stolicy, podejmuje się dawać lekcje na arfie dla tych, którzy już mają dobre początki...21.

\section{Następny anons podaje:}

Umiejący język francuski, niemiecki, łaciński, także doskonały w geografii, w graniu na instrumentach i w innych wielu sztukach wyćwiczony nadgłasza się publice, iż chciałby albo uczyć tego wszystkiego, albo służyć. Ktoby go sobie życzył, niech się uda do rozdającego gazety ${ }^{22}$.

17 Por. Tamże, s. 232-236; M. Mitera-Dobrowolska, Zainteresowanie Komisji Edukacji Narodowej sprawa wychowania dziewcząt, [w:] Ł. Kurdybacha, M. Mitera-Dobrowolska, Komisja Edukacji Narodowej, Warszawa 1973, s. 173-189.

18 H. Vautrin, Obserwator w Polsce, [w:] Polska stanisławowska w oczach cudzoziemców, oprac. W. Zawadzki, t. I, Warszawa 1963, s. 796.

19 M.G. Zieliński, Rola cudzoziemek w procesie edukacji, s. 103-104, 106.

20 "Gazeta Warszawska”, 1797, nr 56, dodatek.

21 "Gazeta Warszawska”, 1786, nr 27, dodatek.

22 "Gazeta Warszawska”, 1787, nr 48, dodatek. 
Prywatni nauczyciele muzyki XVIII wieku to bardzo osobliwi pedagodzy, o wielokierunkowych "specjalnościach" dydaktycznych, których liczba niekoniecznie była równoznaczna z posiadaną wiedzą czy umiejętnościami. Jednak wielu z nich ogłaszało się właśnie między innymi jako nauczyciele od muzyki.

O nauce muzyki w XVIII wieku w Rzeczypospolitej nie głoszono dobrego zdania. Zaliczano ją do tak zwanych talentów przyjemnych, które służyły tylko błyszczeniu w towarzystwie czy po prostu zabawie. Z pewnością nie spełniały celów, jakie stawiali przed edukacją dziewczyn patriotyczni teoretycy wychowania. Sam książę Adam Czartoryski o edukacji muzycznej pisał tak:

Do czegoż (w powszechności mówiąc) większość matek zachęca najżywiej córki swoje i do czego przytrzymuje najbardziej? Do tańca, do muzyki, słowem: do nabycia owych talentów, które pospolicie pod nazwiskiem talentów przyjemnych chodzą. A jakiż jest powód w tej mierze tak wielkiej ich troskliwości? Gdyby chciały wejrzeć w siebie i rzetelnie się przyznać znalazłoby się pewnie, że najczęściej chęć prowadzi je tylko do popisania się z córkami na balu lub na koncercie, chęć odbierania pochwał od przytomnych po wytańcowanym składnie przez córki czyli almandzie, czyli kozaku, po wyśpiewanej gładko aryi, czyli wygranej sonacie, a częstokroć jeszcze miesza się do tego i nadzieja zagaszenia córek tych znowu osób, które im zawadzają lub też drobnych a niesprawiedliwych ich nienawistek są obiektem ${ }^{23}$.

Czartoryski zauważał, że snobizm i powierzchowność społeczeństwa szlacheckiego przysłaniały inne, bardziej zasadnicze na ten czas cele. Postulował dla dziewcząt wychowanie narodowe i obywatelskie, którego pozbawiona była edukacja tradycyjna.

Z pewnością gra na instrumentach, śpiew, czy taniec przydawały się do błyszczenia na balach czy spotkaniach towarzyskich. Tego blichtru dziewczęta uczyły się już od dzieciństwa, kiedy w wieku 4 czy 5 lat rozpoczynały swoją zwyczajową edukację ${ }^{24}$. Uczęszczały wtedy na bale, do których przygotowania wcale nie były takie błahe. Oprócz dzieci zapraszane były na nie również osoby dorosłe, a młodszym tak samo usługiwali służący, jak na balach dla dorosłych. Wystrojone dziewczynki tańczyły z całą powagą, naśladując gesty, mimikę twarzy i ruchy osób dorosłych, szybko ucząc się sztuki występowania i błyszczenia. Wydarzenia te opisuje w swoich wspomnieniach Fryderyk Schulz (1762-1798), który przebywał w Rzeczypospolitej Obojga Narodów w latach 1791-1793:

Ubierają małe tancerki i tancerzy z takim zbytkiem, jak starsi stroić się zwykli. (...) Dzieci obchodzą się z sobą z galenterią, a dziewczęta szczególniej z zalotnością nie

${ }^{23}$ A. Czartoryski, Drugi list Imć Pana Doświadczyńskiego, s. 296.

${ }^{24}$ Por. W. Fiszerowa, Dzieje moje własne i osób postronnych, przekł. E. Raczyński, Warszawa 1998, s. 31; L. Dębicki, Puławy (1762-1830). Monografia z życia towarzyskiego, politycznego i literackiego na podstawie archiwum ks. Czartoryskich w Krakowie, t. 4, Lwów 1888, s. 285. 
ustępującą starszym, która matkom oglądającym w córkach własną młodość łzy pociechy z oczów wyciska. (...) Niecierpliwość, z jaką dzieci na powtórzenie tych balów czekają, niepokój, z jakim zapowiedzianych się dopominają, okazują dostatecznie, jak silnie ta zabawa czyni na nich wrażenie i jak ona pochłaniać je będzie, gdy uczucia wzmogą się i dojrzeją ${ }^{25}$.

Bale dla dorosłych olśniewały tak samo jak bale dziecięce. Baron Karol Henryk von Heyking, pułkownik i dyplomata, przebywając w Rzeczypospolitej w II połowie XVIII wieku, brał udział w licznych i różnych spotkaniach towarzyskich. Pisał, że „nie było nic bardziej czarującego jak takie bale" ${ }^{26}$. W prawdziwy zachwyt podczas tych wydarzeń (co wielokrotnie powtarzał) wprawiała szczególnie płeć piękna:

Kobiety polskie w ogóle wyróżniają się pięknością i wdziękiem, wprawiając w zachwyt cudzoziemców. Wszystkie prawie mówią bardzo biegle po francusku i niemiec$\mathrm{ku}, \mathrm{często} \mathrm{również} \mathrm{po} \mathrm{angielsku} \mathrm{i} \mathrm{włosku,} \mathrm{uprawiają} \mathrm{muzykę,} \mathrm{śpiew} \mathrm{i} \mathrm{malarstwo}{ }^{27}$.

Talenty przyjemne, do których zaliczano właśnie muzykę, nie spełniały założeń pedagogów-reformatorów oświecenia, którzy uważali je wyłącznie za ozdobę kobiety. Jednak szlachta polska w tym czasie dość często obcowała z muzyką. Na jej umuzykalnienie z pewnością miały wpływ elitarne bursy muzyczne coraz liczniejsze w II połowie XVIII wieku oraz kapele magnackie (ponad 602). Muzyka była cały czas obecna w domach szlacheckich, a wzajemne wizyty stanowiły pretekst do miłego spędzenia czasu i wysłuchania gry na instrumentach czy śpiewu członków rodziny. W rodzinie Aloy odgrywała ona szczególną rolę. Jan Baptysta d'Aloy (zm. 1786) ${ }^{29}$, pułkownik wojsk koronnych i konsyliarz wojenny, wraz z żoną Henryką Rakocy mieli dwie córki i dwóch synów. Obie córki pułkownika Anna i Ludwika słynęły z piękności i cieszyły się wielkim powodzeniem w Warszawie. Kiedy złożył im wizytę baron von Heyking, pierwszym widokiem jaki zastał była Anna siedząca przy klawesynie. Po przywitaniach i ogólnej konwersacji do instrumentu zasiadła Ludwika, która „po krótkiej przygrywce zaśpiewała wzruszającą i wzniosłą pieśń Hassego (...). Nigdy nie słyszałem tak niebiańskiej muzy$\mathrm{ki}^{\prime \prime 30}$. Okazało się jednak, że cała rodzina d’Aloy była uzdolniona muzycznie,

${ }^{25}$ F. Schulz, Podróże Inflantczyka z Rygi do Warszawy i po Polsce w latach 1791-1793, [w:] Polska stanistawowska, t. II, s. 592.

${ }^{26}$ K.H. Heyking, Wspomnienia z ostatnich lat Polski i Kurlandii (1752-1796), [w:] Polska stanistawowska, t. I, s. 62.

${ }^{27}$ Tamże, s. $62-63$.

${ }^{28}$ H. Feicht, Nowe spojrzenie na muzykę polską XVIII wieku, „Z dziejów muzyki polskiej”, z. 7, Bydgoszcz 1964, s. 8.

${ }^{29}$ W. Konopczyński, D’Aloy Jan Baptysta, [w:] Polski Stownik Biograficzny, t. 1, Kraków 1935, s. $80-81$.

${ }^{30}$ K.H. Heyking, Wspomnienia z ostatnich lat Polski i Kurlandii, s. 53. 
gdyż dalej Heyking wspominał: „Rozprawialiśmy jeszcze nieco o muzyce, po czym bracia jej wzięli skrzypce i grali trio. Spędziwszy kilka rozkosznych godzin powróciłem do domu pełen nowych myśli i wrażeń" ${ }^{31}$. Kobiety śpiewające czy grające na instrumentach często mimochodem przewijają się we wspomnieniach gości z zagranicy. Słynny niemiecki uczony Jerzy Forester (1754-1794), pisał o towarzyskich odwiedzinach: „Po obiedzie nadeszła szambelanowa Bronikowska, która śpiewała i grała na fortepianie" ${ }^{\prime 32}$. Muzyka zewsząd otaczała wyższe warstwy, czy to w codziennych spotkaniach czy na dużych balach. Jak pisał Fryderyk Schulz: „wyższe klasy lubiły szczególniej muzykę, która część ich wychowania stanowiła"33.

Już w Polsce doby Augusta II i Augusta III Wettynów najpowszechniejszą formą edukacji muzycznej wśród kobiet była gra na klawicymbale, pod kierunkiem nauczycieli sprowadzanych z zagranicy ${ }^{34}$. Należy zaznaczyć jeszcze, że do późnych lat XVIII wieku w powszechnym użyciu był termin klawikord, obejmujący zarówno właściwie klawikordy, jak i fortepiany. Wynikało to zapewne $\mathrm{z}$ tego, że $\mathrm{w}$ języku niemieckim, gdzie powstawały pierwsze tego typu instrumenty, terminu Klavier używano na określenie każdego chordofonu klawiszowego ${ }^{35}$. Nie wiemy, w jakim stopniu szlachta polska rozróżniała te instrumenty. Od II połowy XVIII wieku nauka obejmowała także grę na harfie $^{36}$ i należała do zasadniczych przedmiotów kobiecej edukacji ${ }^{37}$. Rodzice poszukiwali zatem odpowiednich nauczycieli i zawierali umowy co do nauki muzycznej swoich pociech. Na przykład, Michał Weyssenhoff (17151789), podkomorzy królewski, podpisał 6 października 1786 roku kontrakt z nauczycielem muzyki Janem Cybulskim. Zastrzegał sobie przy tym, że chce, aby ten uczył nie tylko jego synów, ale także dwie córki na klawicymbale oraz harfie, wyznaczając mu przy tym pięćdziesiąt czerwonych złotych pensji na rok $^{38}$. Nauka gry nie była nigdy zaniedbywana, nawet w podróżach. Katarzyna z Sosnowskich Platerowa (ok. 1748-1832), ekspisarzowa polna litewska, zabierając w podróż do Włoch swoją córkę Cecylię (1772-1858) zadbała o jej odpowiednią edukację. Przebywając w Rzymie, jednym ze współczesnych centrów nauki, kultury i sztuki europejskiej, znalazła odpowiedniego nauczyciela. Pan Lorenzo Pelli, kapelmistrz w kościele św. Andrzeja i autor

\footnotetext{
31 Tamże.

${ }^{32}$ J. Forester, Dziennik podróży po Polsce, [w:] Polska stanistawowska, t. II, s. 65.

${ }^{33}$ F. Schulz, Podróże Inflantczyka, s. 508.

${ }^{34}$ J. Prosnak, Polihymnia ucząca: wychowanie muzyczne w Polsce od średniowiecza do dni dzisiejszych, Warszawa 1976, s. 43.

35 W. Kamiński, Instrumenty muzyczne na ziemiach polskich, Kraków 1971, s. 122.

${ }^{36}$ C. Sachs, Historia instrumentów muzycznych, przekł. S. Olędzki, Kraków 1989, s. 375.

37 J. Prosnak, Polihymnia uczaca, s. 61.

${ }^{38}$ Litewskie Państwowe Archiwum Historyczne w Wilnie, zespół 1505, sygn. 224, Kontrakt między Michałem Weyssenhoffem i nauczycielem muzyki Janem Cybulskim.
} 
sonat klawesynowych, miał dawać jej córce lekcje śpiewu i gry na klawesynie $^{39}$. Platerowa pilnowała edukacji muzycznej swojej córki także w dalszej podróży. Przebywając w Paryżu, zatrudniła nauczyciela gry na harfie. Cecylia doskonaliła się tam także w śpiewie i tańcu tak, że gdy wróciła do kraju otrzymywała same pochwały. „W istocie śpiewa i tańcuje $\mathrm{z}$ prawdziwym wdziękiem, jakiego nabyła świeżo w Paryżu" ${ }^{\prime 0}$ - relacjonowała matce, Ludwice z Poniatowskich Zamoyskiej (1728-1797), w liście z 17 marca 1787 roku, Urszula Mniszchowa (1750-1806) ${ }^{41}$. Barbara z Duninów Sanguszkowa (17181791), marszałkowa litewska ${ }^{42}$, dama czasów saskich jak i stanisławowskich, również uważała, że muzyka jest niezbędnym elementem edukacji jej córek: Anny, Krystyny i Kunegundy. Wszystkie pobierały lekcje gry na klawesynie i skrzypcach. Podobnie było z jej wnuczką Marianną, która w czasie wizyt u księżnej Barbary nie tylko uczyła się grać, ale także sama komponowała tańce polskie, wykonywane później przez muzyków babki ${ }^{43}$.

Jednak dla wielu młodych arystokratek nauka muzyki nie była przyjemnością. Nieprzykładanie się do lekcji i ćwiczeń surowo karano. Zofia z Czartoryskich Zamoyska (1778-1837), najmłodsza córka Adama Kazimierza Czartoryskiego i Izabeli z Flemingów (1746-1835) pisała: „Miałam dobrego metra od fortepianu, który mnie bił czasem, a ja bardzo płakałam, ale uczył dobrze i byłabym dobrą muzyczką, gdybym była zawczasu nie zaniedbała tego talentu" ${ }^{44}$. Nieprzyjemne wspomnienia związane z nauką gry miała również Henrieta z Działyńskich Błędowska (1794-po 1860), którą uczył pan Gabel rzadko zadowolony z jej postępów. Za nieprzykładanie się do lekcji Henrietę często karano rózgą ${ }^{45}$.

Pomimo różnych doświadczeń z nauką muzyki, polskich szlachcianek zasiadających przy instrumentach było dość dużo. Księżna Helena z Przeździeckich Radziwiłłowa (1753-1821) ${ }^{46}$ zabawiała swoich gości śpiewem i grą

${ }^{39}$ K. z Sosnowskich Platerowa, Moja podróż do Włoch. Dziennik z lat 1785-1786, wstęp i oprac. M.E. Kowalczyk, przekł. z franc. A. Pikor-Półtorak, Łomianki 2013, s. 135.

${ }^{40}$ Cyt. za: M.E. Kowalczyk, Wstęp, [w:] K. z Sosnowskich Platerowa, Moja podróż do Wtoch, s. 46 .

${ }^{41}$ H. Wereszycka, Mniszchowa z Zamoyskich 1. v. Potocka Urszula, [w:] Polski Stownik Biograficzny, t. 21, Wrocław - Warszawa - Kraków - Gdańsk 1976, s. 457-458.

42 E. Aleksandrowska, Sanguszkowa z Duninów Barbara, [w:] Polski Słownik Biograficzny, t. 34, Wrocław - Warszawa - Kraków 1992-1993, s. 517-521.

43 A. Jakuboszczak, Sarmacka dama. Barbara Sanguszkowa (1718-1791) i jej salon towarzyski, Poznań 2008, s. 194.

${ }^{44}$ Kufer Kasyldy, czyli wspomnienia z lat dziewczęcych, Wyboru z pamiętników XVIII-XIX w. dokonały D. Stępniewska, B. Walczyna, Warszawa 1974, s. 20.

45 H. z Działyńskich Błędowska, Pamiątka przeszłości. Wspomnienia z lat 1794-1832, oprac. K. Kostenicz, Z. Makowiecka, Warszawa 1960, s. 37.

46 A. Ryszkiewicz, Radziwiłłowa z Przeździeckich Helena, [w:] Polski Słownik Biograficzny, t. 30, Wrocław - Warszawa - Kraków - Gdańsk - Łódź 1987, s. 390-392. 
na harfie ${ }^{47}$. W Białymstoku podczas spotkań towarzyskich grała na klawikordzie Izabela z Potockich Branicka (1730-1808) ${ }^{48}$. Z inwentarza pałacu w Laszkach, sporządzonego po śmierci kasztelana krakowskiego, Józefa Mniszcha (1670-1747) ${ }^{49}$ wynika, że znajdowały się tam klawicymbał i klawikord. Zatem, możemy przypuszczać, że grały na nich córki właściciela pałacu: Teresa, Elżbieta i Ludwika oraz jego żona Konstancja z Tarłów ${ }^{50}$. Talentami muzycznymi mogła poszczycić się Izabela z Flemmingów Czartoryska (1746-1835). Malarz i grafik Giuseppe Marchi wykonał nawet portret księżnej siedzącej przy klawikordzie z nutami w rękach. Natomiast, portret z nutami Izabeli z Lubomirskich Potockiej utrwalił Pompeo Batonii ${ }^{51}$. Również Christian Gottlieb Geissler w 1791 roku wykonał rysunek ołówkiem, na którym przedstawił scenę muzykowania. Przy klawikordzie zasiada księżna Izabela z Czartoryskich Lubomirska, jej wychowanek Henryk Lubomirski (1777-1850) ${ }^{52}$ gra na harfie, jeden $\mathrm{z}$ francuskich arystokratów - na flecie, drugi zaś trzyma nuty. Całemu towarzystwu asystuje pies ${ }^{53}$. Księżna Izabela mogła też poszczycić się swoją córką Julią, która grą na klawicymbale popisywała się w Puławach przed królem $^{54}$. Nieodłącznym towarzyszem gry na instrumentach był śpiew. Rzadko kiedy wspominano o nim oddzielnie. Szczególnie zachwycano się głosem wojewodziny wileńskiej, Heleny z Przeździeckich Radziwiłłowej, która podobno umiała „poruszać śpiewem kamienie” ${ }^{55}$.

Oprócz gry na instrumentach młodzież żeńska prawdopodobnie zapoznawała się z podstawowymi elementami teorii muzyki. Niestety, nie zachował się z tego okresu prawie żaden zapis ćwiczeń teoretycznych, oprócz Katechizmu muzycznego z 1750 roku pochodzącego z sandomierskiego konwentu benedyktynek ${ }^{56}$. Klasztor ten był jednym z ośrodków muzycznych, gdzie kilka kolejnych generacji zakonnic angażowało się w działalność kapeli wokalno-instrumentalnej, kultywując tym samym muzykę profesjonalną ${ }^{57}$.

47 E. A. von Lehndorff, Dzienniki, [w:] Polska stanisławowska, t. II, s. 34.

48 W. Konopczyński, Branicka Izabela, [w:] Polski Słownik Biograficzny, t. 2, Kraków 1936, s. 396-397.

49 H. Perzanowska, Mniszech Józef, [w:] Polski Słownik Biograficzny, t. 21, Wrocław - Warszawa - Kraków - Gdańsk 1976, s. 474-478.

${ }^{50}$ K. Stasiewicz, Kobiece przyjemności w XVIII wieku, [w:] Przyjemność w kulturze epoki rozu$m u$, red. T. Kostkiewiczowa, Warszawa 2011, s. 131.

51 M.E. Kowalczyk, Zagraniczne podróże Polek w epoce oświecenia, Łomianki 2019, s. 340.

${ }^{52}$ M. Tyrowicz, Lubomirski Henryk, [w:] Polski Słownik Biograficzny, t. 18, Wrocław - Warszawa - Kraków 1973, s. 9-11.

53 M.E. Kowalczyk, Zagraniczne podróże Polek, s. 347.

54 K. Stasiewicz, Kobiece przyjemności, s. 131.

55 Cyt. za: S. Wasylewski, Portrety pań wytwornych, Warszawa 2011, s. 33.

56 J. Prosnak, Polihymnia uczaca, s. 42.

57 M. Walter-Mazur, Panny z okładek. Zakonnice aktywne muzycznie w klasztorach benedyktynek w XVIII wieku, Śląski Kwartalnik Naukowy, 2013, 3(33), s. 62. 
Jeden z wykładów Marianny Moszyńskiej (ur. ok. 1715), córki cześnika urzędowskiego Stanisława ${ }^{58}$, zawarty w Katechizmie: Principia albo początki należace uczacemu się śpiewania figuratu objaśniał zagadnienia systemu solmizacyjnego, klucze, takty, wartości nut i tym podobne ${ }^{59}$. Warto podkreślić, że do sandomierskiego klasztoru trafiały dziewczęta z pewnym przygotowaniem muzycznym. Były to córki muzyków lub dziewczęta z rodzin szczycących się herbem i urzędami w Rzeczypospolitej, które umieszczały córki w klasztorach wpłacając odpowiedni dla stanu posag ${ }^{60}$.

Wydaje się, że nauka gry i śpiewu służyła $w$ większości rozrywce salonowej. Dziewczęta uczyły się grać i muzykować na tyle, by móc mile spędzać czas w towarzystwie. Nie szczególnie skupiano się na rozwoju ich talentów. Wspominał o tym Fryderyk Schulz:

Wiele miłych głosów znaleźć było można wśród pań i panów (...). Ale nadzwyczajnego nic sobie nie przypominam, może $z$ tego powodu, że polski charakter zanadto jest płochy, a życie ich nadto rozerwane, by mogli czas i cierpliwość znaleźć na wykształcenie jakiegokolwiek talentu. Umiano tylko osobliwym wdziękiem i lekkością podnieść wrodzony talent, któremu prawie zawsze towarzyszyła figura piękna i od natury dany dar podobania się ${ }^{61}$.

Na potwierdzenie zdania, jak zachwycający potrafił być to widok, Schulz pisał o Helenie z Przeździeckich Radziwiłłowej i jej dzieciach:

Tak na przykład nie można sobie wystawić nic piękniejszego nad obraz księżnej Radziwiłłowej z czworgiem swych dzieci przy muzyce. Księżna była jeszcze wcale piękna, a twarz wiele słodyczy i czułości w rysach miała. Dwaj jej synowie, młodzi wykształceni kawalerowie, córka, księżniczka Krystyna szesnastoletnia, księżniczka Aniela czternaście lat mająca - obie, każda w swoim rodzaju, zachwycające, zajmowały się z upodobaniem muzyką pod przewodnictwem zachęcającej je do tego matki. Wielce było przyjemnym słuchać tercetów, które księżna z dwoma synami swymi, to z córkami wykonywała, a milej jeszcze napawać widokiem tej miłości macierzyńskiej i dziecięcej, która w Warszawie wcale pospolitą nie była. W towarzystwach, w których ta matka znajdowała się i słyszeć dawała, nie zbywało na serach męskich, na których głos jej szczególnie, większe niż na pospolitych słuchaczach, wywierał wrażenie ${ }^{62}$.

Ten idylliczny obraz z pewnością zachwycał wszystkich, a zwłaszcza mężczyzn. To już kolejny przykład pokazujący, w jaki zachwyt wpadali panowie, widząc piękne, muzykujące kobiety.

\footnotetext{
${ }^{58}$ Tamże, s. 58.

59 J. Prosnak, Polihymnia ucząca, s. 43-45.

${ }^{60}$ M. Walter-Mazur, Panny z okładek, s. 58.

${ }^{61}$ F. Schulz, Podróże Inflantczyka, s. 508.

${ }^{62}$ Tamże, s. 509.
} 
Na kolejnych stronach swoich wspomnień o stolicy Rzeczypospolitej Schulz nadal odnosił się do tego, że wśród Polaków nie było większego zainteresowania muzyką, która pozwoliłaby na wykształcenie prawdziwych wirtuozów.

Upodobanie w muzyce jest w Warszawie powszechne, zwłaszcza w wyższych stanach i bliskich im kołach, więcej wszakże u kobiet niż między mężczyznami. (...) Chociaż muzykę lubią bardzo, brak znajomości jej głębszej najwykształceńszym i prawdziwego zamiłowania. To, co się w towarzystwie śpiewa i po czym tańcować można, najwięcej do smaku polskiego przypada. Wirtuozi, którzy tu czasem przybywają, muszą o tym wiedzieć, inaczej by nie potrafili zapewnić tu sobie dobrego przyjęcia. Słyszałem tu w ciągu lat 1791 i 1792 wielu z nich, którzy gdzie indziej nie znaleźli współczucia, tu zaś słuchano ich bardzo łaskawie, a nawet przyklaskiwano ${ }^{63}$.

Jak się okazuje, Polacy nie mieli dużych wymagań jeśli chodziło o ich gust muzyczny. Chętnie słuchali różnej jakości muzyki, ale nie oznaczało to, że nie zapraszali prawdziwych mistrzów i wirtuozów. Bardzo popularne w tym czasie były koncerty Eleonory Zernitz (ur. Deeling), która zachwycała swoich słuchaczy wirtuozerią fortepianu:

trudno chyba gruntowniej, niż to ona zrobiła, przeniknąć tajniki muzyki, z większym geniuszem zgłębić i zastosować w praktyce różne kunsztowne chwyty i kompozycyjne, w wykonaniu przejawić więcej wyrazu, lekkości, blasku i siły, słowem - z większą precyzją wydobyć z fortepianu wszystko, na co ten instrument stać ${ }^{4}$.

Natomiast, polskie szlachcianki swoją grą nie wyróżniały się ponad przeciętność. Wyjątkiem była Maria Szymanowska, z domu Wołowska (17891831), jedna z pierwszych profesjonalnych pianistek w Europie, która komponowała także liczne utwory wokalne i fortepianowe, chociaż nigdy nie odebrała lekcji kompozycji. Maria otrzymała staranne wykształcenie, jak każda dziewczyna z dobrego domu w tym czasie; uczyła się języka francuskiego, czytała umoralniające książki, oraz grała na instrumencie. Swoje lekcje gry na fortepianie dziewczyna rozpoczęła w wieku 8 lat. Pod kierunkiem pierwszego nauczyciela przez dwa lata robiła takie postępy, że ten polecił jej rodzicom, by powierzyli jej naukę pianiście Tomaszowi Gremmowi. Lekcje z nim trwały około czterech lat i to prawdopodobnie od niego Marynia - jak ją pieszczotliwie nazywano $\mathrm{w}$ domu - przejęła pewne kompozytorskie nawyki ${ }^{65}$. W późniejszym czasie kształciła się już samodzielnie. Warto też zauważyć, że salon jej rodziców, Franciszka Wołowskiego i Barbary z Lanckorońskich, nigdy nie był pusty. Bywało tutaj wielu muzyków, którzy występowali dla Wołowskich

\footnotetext{
63 Tamże, s. 618.

${ }_{64}$ J. Bernoulli, Podróż po Polsce 1778, [w:] Polska stanistawowska, t. I, s. 369-369.

${ }^{65}$ I. Bełza, Maria Szymanowska, Kraków 1987, s. 15-16, 25.
} 
lub mieli okazję słuchać gry Marii i się nią zachwycaćc6. W każdym warszawskim salonie, $\mathrm{w}$ tym i u Wołowskich, wykonywane były popularne $\mathrm{w}$ tym czasie polonezy Michała Kleofasa Ogińskiego (1765-1833) ${ }^{67}$ czy utwory Józefa Elsnera (1769-1854), wybitnego działacza muzyki polskiej i słynnego pedagoga $^{68}$. Marynia dużo uczyła się z ich dzieł, a jej pierwsze utwory zdradzają związek z twórczymi poszukiwaniami kompozytorów polskich ${ }^{69}$. Dalszy rozwój muzyczny pani Szymanowskiej wychodzi już poza rozważania epoki oświecenia, jednak początki jej edukacji muzycznej mogą nam obrazować wychowanie muzyczne tych czasów. Marii nie starczało tylko muzykowanie salonowe; dążyła do tego by stać się muzykiem zawodowym ${ }^{70}$. Upartość, cierpliwość w ćwiczeniach i analizie utworów oraz miłość do muzyki pomagały jej w dążeniu do celów. Trzeba również podkreślić, że miała ona dość ułatwione zadanie, gdyż wychowywała się w rodzinie bardzo muzycznej, która śledziła pilnie nowinki w tej dziedzinie. Nie w każdej rodzinie szlacheckiej panowało tak silne przywiązanie do tej sfery życia.

W XVIII wieku edukację muzyczną rozumiano nie tylko jako naukę śpiewu czy gry na instrumencie, ale także jako naukę tańca. Już w Ustawach szkolnych pijara i reformatora szkolnego czasów saskich Stanisława Konarskiego (1700-1773) ${ }^{71}$ pisano, kiedy takie lekcje powinny się odbywać. Sam zresztą Konarski, wprowadzając swoje pedagogiczno-dydaktyczne novum, odnosił się do wskazań filozofa i pedagoga ateńskiego Platona, który aprobował taniec o walorach estetycznych i artystycznych, kształcący zarówno duszę i ciało. Uważał go za doniosły czynnik o znaczeniu wychowaw$\operatorname{czym}^{72}$. Toteż, od najmłodszych lat każda szlachcianka uczyła się kroków oraz rytmu. Zofia z Czartoryskich Zamoyska z przyjemnością wspominała zajęcia z metrem tańca:

Te lekcje bawiły mnie bardzo, a ponieważ dobrze tańczyłam i bardzo mnie z tego chwalono, rozbudziło się we mnie zanadto wielkie umiłowanie tańca, jakby rzeczy ważnej ${ }^{73}$.

Matka Zofii, Izabela z Flemingów Czartoryska, mogła się chwalić tańcem obu córek przy różnych spotkaniach towarzyskich:

${ }^{66}$ Tamże, s. 27.

${ }^{67}$ Z. Libiszowska, A. Nowak-Romanowicz, Ogiński Michat, [w:] Polski Stownik Biograficzny, t. 23, Wrocław - Warszawa - Kraków - Gdańsk 1978, s. 630-636.

${ }^{68}$ Z. Jachimecki, Elsner Józef, [w:] Polski Stownik Biograficzny, t. 6, Kraków 1948, s. 235-237.

${ }^{69}$ I. Bełza, Maria Szymanowska, s. 17, 20.

${ }^{70}$ Tamże, s. 27.

${ }^{71}$ J. Michalski, Konarski Hieronim, [w:] Polski Stownik Biograficzny, t. 13, Wrocław - Warszawa - Kraków 1967-1968, s. 471-477.

72 J. Prosnak, Polihymnia uczaca, s. 36.

${ }^{73}$ Kufer Kasyldy, czyli wspomnienia z lat dziewczecych, s. 20. 
powróciliśmy do domu, gdzie dwie najstarsze córki księżnej, z najbardziej elegancką prostotą ubrane $\mathrm{w}$ greckie szaty, odtańczyły polski i kozacki taniec: pierwszy z wdziękiem i powagą, drugi z życiem i humorem ${ }^{74}$.

Także Barbara Sanguszkowa zdawała sobie sprawę, że dziewczynki trzeba przygotować do bywania $\mathrm{w}$ towarzystwie i podejmowała starania $\mathrm{w}$ poszukiwaniu odpowiedniego nauczyciela tańca. Początkowo planowano go sprowadzić z Paryża, gdyż to miasto wydawało się do tego najodpowiedniejsze. Jednak z czasem okazało się, że sprowadzenie takiego nauczyciela było zbyt kosztowne. Barbara w końcu znalazła metra tańca, którego nazwiska niestety nie znamy. Wiemy natomiast, że nie przypadł on do gustu uczniom przez swoje dziwne maniery, toteż księżna zawarła w 1751 roku umowę z nowym nauczycielem, Monsieur Durandem. Umowa między nimi zakładała, że będzie udzielał lekcji wszystkim jej dzieciom, zarówno chłopcom jak i dziewczętom, godzinę rano i godzinę po południu. W zamian metr oczekiwał zapewnienia mu mieszkania, wyżywienia i 80 dukatów za dawane lekcje. Zastrzegał sobie również, że będzie mógł mieć innych uczniów. Ostatecznie Durand otrzymywał za swoją pracę 150 dukatów, ale oprócz lekcji tańca udzielał również lekcji śpiewu ${ }^{75}$.

Dominującym i najbardziej reprezentacyjnym tańcem polskim $w$ tym czasie był polonez, nazywany po prostu "tańcem polskim" lub nawet "tańcem”. Był jedyny, w którym szlachta mogła w całej okazałości wystąpić w bogatych i ozdobnych strojach. Wszystkie inne tańce polskie, nawet zagraniczne, były w Polsce tańcami drugorzędnymi ${ }^{76}$, ale nie odmawiano zabawy przy każdym z nich.

Taniec, dusza polskich zabaw, nigdzie może na świecie z większym wdziękiem, lekkością, z większą namiętnością i przejęciem nie był wykonywanym. Szczególniej piękne dwa narodowe tańce, polski i mazur, oba zupełnie od siebie charakterem różne, ale mogące być do najwyższej doskonałości sztuką i wdziękiem postaci doprowadzone ${ }^{77}$.

W epoce oświecenia muzykują wszystkie szlachcianki należące do różnych pokoleń. Każda kobieta z wyższych sfer mogła podejść do instrumentu, wyciągnąć nuty i zaśpiewać dla umilenia czasu spędzanego w towarzystwie. Płeć piękna umiała także bawić się na balach czy mniejszych przyjęciach oraz dobrze tańczyć, z odpowiednią postawą i krokami dostosowanymi do różnych rodzajów tańców. Jednakże, aby posiąść takie umiejętności, musiały zostać odpowiednio wychowane. Rodzice dbali, żeby ich pociechy miały

\footnotetext{
${ }^{74}$ W. Coxe, Podróż po Polsce 1778, [w:] Polska stanistawowska, t. I, s. 662-664.

75 A. Jakuboszczak, Sarmacka dama, s. 75-76.

${ }^{76}$ K. Hławiczka, Z dziejów poloneza, „Z dziejów muzyki polskiej”, z. 7, Bydgoszcz 1964, s. 38.

77 F. Schulz, Podróże Inflantczyka, s. 509.
} 
stosownych nauczycieli, którzy mogliby im przekazać wiedzę muzyczną. Zatem, okazuje się, że zwyczajową edukacją, oprócz pisania, czytania, historii i innych, była nauka gry, śpiewu, czy tańca nie tylko w Polsce, ale i w Europie. Pomimo tego, ówcześni polscy teoretycy wychowania nie wspominali o niej, lub słowa "nauka muzyki" padały mimochodem przy innych wymienionych przedmiotach przeznaczonych dla nauki dziewcząt. Spotykamy się nawet z negatywną opinią o edukacji muzycznej, która miała budzić w nich próżność. Nie było to mile widziane, kiedy kraj potrzebował świadomych obywatelek-patriotek.

Pomimo różnych zdań odnośnie nauczania muzyki, była ona stale obecna w życiu polskiej szlachty czasów oświecenia. Służyła między innymi przyjemnemu spędzaniu czasu czy wspólnej zabawie. Z pewnością także widok wystrojonej damy zasiadającej przy instrumencie czy śpiewającej mógł wprawiać $\mathrm{w}$ zachwyt. Szlachcianki w towarzystwie po prostu błyszczały nie tylko z uwagi na wygląd, ale właśnie z powodu umiejętności muzycznych. Wydaje się, że taki był sens tej edukacji: brylować w towarzystwie, oczarowywać gości i olśniewać tak zwanymi talentami przyjemnymi. Przecież wszystkie te zabiegi i starania o jak najlepsze wychowanie i wykształcenie miały jeden cel: wydanie panny odpowiednio za mąż. Kobieta z takimi umiejętnościami muzycznymi mogła śmiało wkraczać w towarzystwo i podbijać męskie serca w poszukiwaniu dobrego i majętnego męża.

\section{BILBIOGRAFIA}

\section{Źródła rękopiśmienne}

Litewskie Państwowe Archiwum Historyczne w Wilnie, zespół 1505, sygn. 224, Kontrakt między Michałem Weyssenhoffem i nauczycielem muzyki Janem Cybulskim.

\section{Źródła drukowane}

Aleksandrowska E., Piramowicz Grzegorz Wincenty, [w:] Polski Słownik Biograficzny, t. 26, Wrocław - Warszawa - Kraków - Gdańsk - Łódź 1981.

Aleksandrowska E., Sanguszkowa z Duninów Barbara, [w:] Polski Słownik Biograficzny, t. 34, Wrocław - Warszawa - Kraków 1992-1993.

Bernoulli J., Podróż po Polsce 1778, [w:] Polska stanisławowska w oczach cudzoziemców, oprac. W. Zawadzki, t. I, Warszawa 1963.

Bieliński F., Sposób edukacji w XV listach opisany, które do Komisji Edukacji Narodowej od bezimiennego autora byly przesyłane R. P. 1775, [w:] Pisma i projekty pedagogiczne doby Komisji Edukacji Narodowej, Wrocław - Warszawa - Kraków - Gdańsk 1973.

Błędowska H. z Działyńskich, Pamiątka przeszłości. Wspomnienia z lat 1794-1832, oprac. K. Kostenicz, Z. Makowiecka, Warszawa 1960. 
Coxe W., Podróż po Polsce 1778, [w:] Polska stanistawowska w oczach cudzoziemców, oprac. W. Zawadzki, t. I, Warszawa 1963.

Czartoryski A., Drugi list Imć Pana Doświadczyńskiego do przyjaciela swego względem edukacyi córek [w:] S. Tync, Komisja Edukacji Narodowej: (pisma Komisji i o Komisji): wybór źródet, Wrocław 1954.

Feicht H., Nowe spojrzenie na muzykę polska XVIII wieku, „Z dziejów muzyki polskiej”, z. 7, Bydgoszcz 1964.

Fiszerowa W., Dzieje moje własne i osób postronnych, przekł. E. Raczyński, Warszawa 1998.

Forester J., Dziennik podróży po Polsce, [w:] Polska stanistawowska w oczach cudzoziemców, oprac. W. Zawadzki, t. II, Warszawa 1963.

"Gazeta Warszawska", 1786, nr 27, dodatek.

"Gazeta Warszawska", 1787, nr 48, dodatek.

"Gazeta Warszawska”, 1797, nr 56, dodatek.

Heyking K.H., Wspomnienia z ostatnich lat Polski i Kurlandii (1752-1796), [w:] Polska stanistawowska w oczach cudzoziemców, oprac. W. Zawadzki, t. I, Warszawa 1963.

Jachimecki Z., Elsner Józef, [w:] Polski Stownik Biograficzny, t. 6, Kraków 1948.

Konopczyński W., D’Aloy Jan Baptysta, [w:] Polski Stownik Biograficzny, t. 1, Kraków 1935.

Konopczyński W., Branicka Izabela, [w:] Polski Słownik Biograficzny, t. 2, Kraków 1936.

Kufer Kasyldy, czyli wspomnienia z lat dziewczęcych, Wyboru z pamiętników XVIII-XIX w. dokonały D. Stępniewska, B. Walczyna, Warszawa 1974.

Lehndorff E.A., Dzienniki, [w:] Polska stanistawowska w oczach cudzoziemców, oprac. W. Zawadzki, t. II, Warszawa 1963.

Libiszowska Z., Nowak-Romanowicz A., Ogiński Michat, [w:] Polski Stownik Biograficzny, t. 23, Wrocław - Warszawa - Kraków - Gdańsk 1978.

Michalski J., Konarski Hieronim, [w:] Polski Stownik Biograficzny, t. 13, Wrocław - Warszawa - Kraków 1967-1968.

Piramowicz G., Powinności nauczyciela mianowicie zaś w szkołach parafjalnych $i$ sposoby ich dopetnienia, oprac. W. Osterloff, Łódź 1919.

Prokopowicz A.M., Sposób nowy, najłatwiejszy, pisania i czytania razem dla panienek, z przypisami dla nauczycielek, Kraków 1790.

Platerowa K. z Sosnowskich, Moja podróż do Wtoch. Dziennik z lat 1785-1786, wstęp i oprac. M.E. Kowalczyk, przekł. z franc. A. Pikor-Półtorak, Łomianki 2013.

Perzanowska H., Mniszech Józef, [w:] Polski Stownik Biograficzny, t. 21, Wrocław - Warszawa - Kraków - Gdańsk 1976.

Rousseau J.J., Emil czyli o wychowaniu, wstęp i oprac. J. Legowicz, t. I, Wrocław 1955.

Ryszkiewicz A., Radziwiłłowa z Przeździeckich Helena, [w:] Polski Słownik Biograficzny, t. 30, Wrocław - Warszawa - Kraków - Gdańsk - Łódź 1987.

Schulz F., Podróże Inflantczyka z Rygi do Warszawy i po Polsce w latach 1791-1793, [w:] Polska stanisławowska w oczach cudzoziemców, oprac. W. Zawadzki, t. II, Warszawa 1963.

Ustawy Komisji Edukacji Narodowej dla stanu akademickiego i na szkoły w krajach Rzeczypospolitej przypisane w Warszawie roku 1783, wstęp J. Lubczyński, Lwów 1930.

Vautrin H., Obserwator w Polsce, [w:] Polska stanistawowska w oczach cudzoziemców, oprac. W. Zawadzki, t. I, Warszawa 1963.

Waniczkówna H., Czartoryski Adam Kazimierz, [w:] Polski Stownik Biograficzny, t. 4, Kraków 1938.

Wereszycka H., Mniszchowa z Zamoyskich 1.v. Potocka Urszula, [w:] Polski Stownik Biograficzny, t. 21, Wrocław - Warszawa - Kraków - Gdańsk 1976.

Wolff A., Budka W., Bieliński Franciszek, [w:] Polski Stownik Biograficzny, t. 2, Kraków 1936. "Zbiór Wiadomości Tygodniowych", 1784, nr 10. 


\section{Literatura}

Bełza I., Maria Szymanowska, Kraków 1987.

Bogucka M., Białogłowa w dawnej Polsce. Kobieta w społeczeństwie polskim XVI-XVIII wieku na tle porównawczym, Warszawa 1998.

Dębicki L., Puławy (1762-1830). Monografia z życia towarzyskiego, politycznego i literackiego na podstawie archiwum ks. Czartoryskich w Krakowie, t. 4, Lwów 1888.

Hławiczka K., Z dziejów poloneza, „Z dziejów muzyki polskiej”, z. 7, Bydgoszcz 1964.

Jakuboszczak A., Sarmacka dama. Barbara Sanguszkowa (1718-1791) i jej salon towarzyski, Poznań 2008.

Kamiński W., Instrumenty muzyczne na ziemiach polskich, Kraków 1971.

Kowalczyk M.E., Zagraniczne podróże Polek w epoce oświecenia, Łomianki 2019.

Libera Z., Problemy polskiego Oświecenia. Kultura i styl, Warszawa 1969.

Mitera-Dobrowolska M., Zainteresowanie Komisji Edukacji Narodowej sprawa wychowania dziewcząt, [w:] Ł. Kurdybacha, M. Mitera-Dobrowolska, Komisja Edukacji Narodowej, Warszawa 1973.

Mrozowska K., Rozwój koncepcji pedagogicznych w XVIII w., [w:] Pisma i projekty pedagogiczne doby Komisji Edukacji Narodowej, Wrocław - Warszawa - Kraków - Gdańsk 1973.

Prosnak J., Polihymnia uczaca: wychowanie muzyczne w Polsce od średniowiecza do dni dzisiejszych, Warszawa 1976.

Przychodzińska M., Wychowanie muzyczne - idee, treści, kierunki rozwoju, Warszawa 1989.

Stetkiewiczówna W., System wychowania kobiet wedtug KEN, Przegląd Pedagogiczny, 1924, z. IV.

Sachs C., Historia instrumentów muzycznych, przekł. S. Olędzki, Kraków 1989.

Stasiewicz K., Kobiece przyjemności w XVIII wieku, [w:] Przyjemność w kulturze epoki rozumu, red. T. Kostkiewiczowa, Warszawa 2011.

Walter-Mazur M., Panny z okładek. Zakonnice aktywne muzycznie w klasztorach benedyktynek w XVIII wieku, Śląski Kwartalnik Naukowy, 2013, 3(33).

Wasylewski S., Portrety pań wytwornych, Warszawa 2011.

Wolińska E., Rola zajęć umuzykalniających w rozwoju dziecka, Konteksty Pedagogiczne, 2017, $1(8)$.

Zieliński M.G., Rola cudzoziemek w procesie edukacji młodzieży w okresie stanistawowskim (1764-1795), [w:] Rola i miejsce kobiet w edukacja i kulturze polskiej, t. 1, red. W. Jamrożek, D. Żołądź-Strzelczyk, Poznań 1998.

Żołądź-Strzelczyk D., "Jako rządzić maja rodzice córki swe". Poglądy na wychowanie kobiet w XVI-XVIII w., [w:] Rola i miejsce kobiet w edukacja i kulturze polskiej, t. 1, red. W. Jamrożek, D. Żołądź-Strzelczyk, Poznań 1998.

Żołądź-Strzelczyk D., Antoniego Maksymiliana Prokopowicza sposób nowy najtatwiejszy pisania $i$ czytania razem dla panienek z przypisami dla nauczycielek - pierwszy polski podręcznik edukacji elementarnej dla dziewcząt, Kwartalnik Historii Kultury Materialnej, 2014, 62, 4. 